\title{
THE QUALITY OF SUPPLIED PARTS AND THEIR INFLUENCE ON MANUFACTURED QUALITY IN SERIAL PRODUCTION
}

doi: 10.2478/cqpi-2019-0069

Date of submission of the article to the Editor: $x x / 11 / 2018$

Date of acceptance of the article by the Editor: $x x / 12 / 2018$

Milan Dian ${ }^{1}$ - orcid id: 0000-0003-2740-7292

1JEP University/Faculty of Mechanical Engineering, in Usti nad Labem Czech Republic

Abstract: The quality of manufactured products itself has long been playing significant role in nowadays business as well as in customers satisfaction with all kinds of products and services provided. Since all of us face to the poor quality results on daily basis, it is necessary to deploy an appropriate set of quality tools in order to improve the total quality level. The quality level of supplied parts in terms of the product quality including the design, development, and manufacturing process has significantly been influencing the quality results of serial production. The contemporary business philosophy for supplier's selection uses merely the only criterion, the lowest price. The article describes some problems stemming from this philosophy and practice, determines a systemic approach and proposes a solution in order to improve supplier's reliability in terms of quality of supplied parts and customer satisfaction.

Keywords: Quality Assurance, SQA (Supplier's Quality Assurance), Supplier`s Reliability

\section{INTRODUCTION}

The significance of contemporary supplied quality of products and materials plays undisputable role in manufacturing and assembly processes. Considering the fact that some of the organizations spend over $60 \%$ of overall costs to purchase the parts (FAU-C-SP-4030/EN, 2002), their performance and customer satisfaction is highly dependent on these delivered parts. To achieve required level of customer's quality, cost and delivery objectives, the organization is determined to establish and develop close and long term relationship with their suppliers. Within the supply chain the customers and suppliers are mutually interdependent upon each other's performance. The contemporary used systems for achieving the goals in terms of "Zero Defect Policy" can be well known as Excellence Systems, Quality Assurance Guides for Production Purchased Parts, CSE Management (Characteristique Securite Esencial), APQP (Advanced Product Quality Planning), PPAP (Production Product Approval Process), etc. Such as systems enables the organization to identify and manage a panel of suppliers in terms of achieving required customer satisfaction. Besides the 
general utilization of later mentioned advanced methodologies the nowadays quality problems across the automotive, aviation and even the food processing industry indicates a plethora of problems stemming from discrepancies to standards causing high amount of customer and internal claims ending up with the recall campaigns accompanied with significant loss. In the modern conception of quality it is necessary to shift from managing into the philosophy of reliability or dependability which expresses stability of delivered batches of parts or material etc. in repeated time in terms of quality, amount, and time (Kocour, 2012). The article main objective is to determine some of the crucial problem generating areas within a range of supply parts deliveries used in serial production, and describe the main root causes having influence on the manufactured quality of final products whilst decreasing the cost from non-conformities occurrence and number of claims. The further discussion confirms the previously mentioned unsatisfied contemporary quality level and uncovers the causes and areas for improvement.

\section{METHODOLOGY OF RESEARCH}

In order to determine a contemporary quality status in supply chain (on the side between supplier - manufacturing organization and manufacturing organization customer) an analysis of claims recorded in claims customer databases (AMADEUS) using G8D reports, Ishikawa cause and effect diagrams, data from NG markets, analysis of APQP, PPAP experience and performing process audits accompanied by ISO/TS 16949:2009 standard, and ISO 9001:20015 compliance as the tools were used. A fundamental document representing generally customers demand in order to comply with customer requirements besides the specifications is the PPAP a part of APQP process. In addition to PPAP these principles are included in IATF 16949:2015 former ISO/TS 16949:2009, ISO 9001:2016, and each customer's „Supplier Quality Guide ,with some small differences. The product supply process can be divided into two fundamental stages. The first one is the production part approval process and the second is the supplier quality management. These two groups can be considered as the basic non-compliance sources for further investigation or as the inner and outer process threats. Mentioning above the PPAP process determines requirements on parts intended to be used in a serial production. The main purpose of the PPAP is to set whether the organization correctly understands to all customer requirements in terms of design documents and whether the manufacturing process is capable to produce capable parts during the serial production with required capacity.

The supplier's development is a long term task when the first step is supposed to be identification of supplier weaknesses. The main areas of importance relating to suppliers area based on ISO/TS 16949:2009 are depicted in table 1 (ISO/TS 16949:2009). 
Table 1

Areas of non-compliance origin related to supply of manufacturing parts within serial production

\begin{tabular}{|l|l|}
\hline $\begin{array}{l}\text { 1. The organization shall determine and } \\
\text { implement effective communication with } \\
\text { customers. }\end{array}$ & $\begin{array}{l}\text { 7. Records established to provide evidence } \\
\text { of conformity to requirements shall be } \\
\text { controlled. }\end{array}$ \\
\hline $\begin{array}{l}\text { 2. Documents required by the quality } \\
\text { management system shall be controlled. }\end{array}$ & $\begin{array}{l}\text { 8. Competence, training and awareness of } \\
\text { activities towards the quality. }\end{array}$ \\
\hline $\begin{array}{l}\text { 3. The organization shall have a process to } \\
\text { assure and timely review, distribution, and } \\
\text { implementation of all customer } \\
\text { standards/specifications in defined time. }\end{array}$ & $\begin{array}{l}\text { 9. The organization shall perform supplier } \\
\text { quality management system with the goal of } \\
\text { supplier conformity with the specification. }\end{array}$ \\
\hline $\begin{array}{l}\text { 4. The organization shall establish and } \\
\text { implement the inspection or other activities } \\
\text { necessary for ensuring that purchased } \\
\text { product meets specified purchase } \\
\text { requirements. }\end{array}$ & $\begin{array}{l}\text { 10. The organization shall ensure that } \\
\text { product which does not conform to product } \\
\text { requirements is identified and controlled to } \\
\text { prevent its unintended use or delivery. }\end{array}$ \\
\hline $\begin{array}{l}\text { 5. Supplier performance shall be ber } \\
\text { monitored. } \\
\text { 6. The organization shall identify the } \\
\text { product by suitable means throughout } \\
\text { product realization. }\end{array}$ & $\begin{array}{l}\text { 11. The organization shall monitor and } \\
\text { measure the characteristics of the product } \\
\text { verify that product requirements have } \\
\text { been met. }\end{array}$ \\
\hline
\end{tabular}

Source: (ISO/TS 16949:2009)

The non-compliance is defined as a failure to act in accordance with a wish or command and having connection to risk itself defined as a danger of an origin of negative deviation from defined objective. The similar expression comes from Taguchi's approach when "whatever deviation from target value is considered as a loss and will have an impact on final user in term of increased costs of maintenance, operation, repairs, ecology, a number of non-compliant parts as well as a decrease of quality assurance level, etc.". Generally spoken, each activity is accompanied by risk and if not understood and eliminated or at least dwindled may result to noncompliance. The each non-compliance with pre-determined realization procedure of observed activity is risky.

\section{RESULTS}

The figure 1 depicts an overview of number of claims connected to final product quality and responsible body. As shown in item SQA (Supplier Quality Assurance) the contribution of non-compliant supplied parts covers $26,79 \%$ of total claimed parts the ones being used for manufacturing. Furthermore, the contribution of organization itself as the supplier, as shown in figure 1 in column "Customer", means the final customer was responsible for $28.57 \%$ of total claimed parts. Above mentioned QCD as the important internal indicator of "how company is doing" has been broaden with a number of customer claims as an external indicator. The figure 1 exhibits and proves the crucial importance of quality of supplied parts in whole production process. The origin and root causes of the claims leads to risks or non-compliances connected to 
purchase parts including their origin, description, and consequences and are described in table 2.

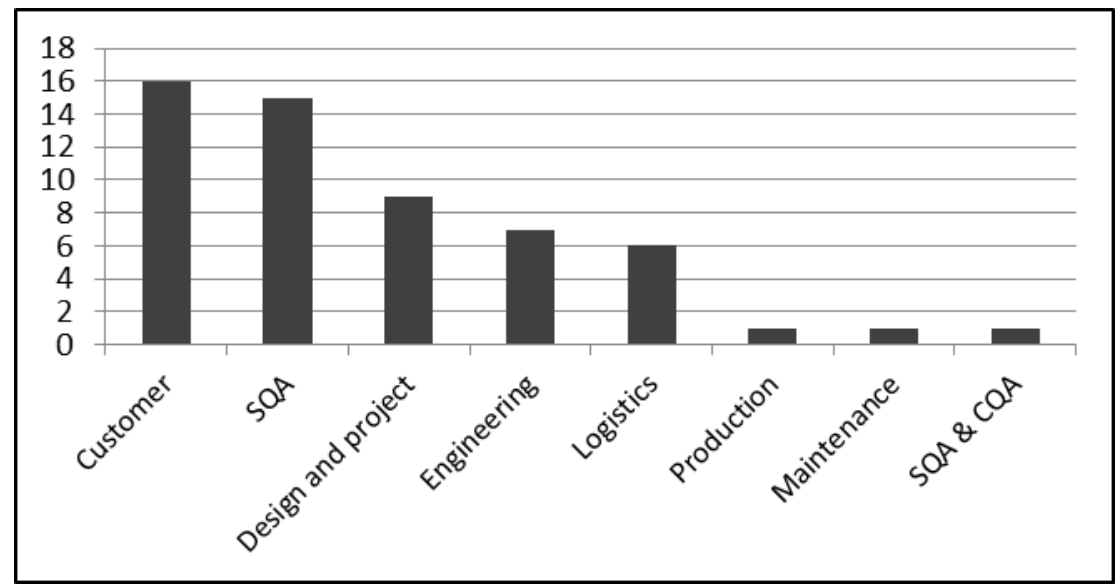

Fig. 1. Distribution and number of claims according to responsible body

Table 2

The non-compliances related to supply of manufacturing parts within production parts approval process

\begin{tabular}{|c|c|c|c|}
\hline Area of origin & Non-compliance & Description & Consequences \\
\hline $\begin{array}{l}\text { 1. Design record and } \\
\text { set of critical to quality } \\
\text { parameters CTQ } \\
\text { (safety, regulation, } \\
\text { key). }\end{array}$ & $\begin{array}{l}\text { 1. Insufficient quality } \\
\text { of drawings. } \\
\text { 2. Too strict } \\
\text { specification } \\
\text { 3. Out of date } \\
\text { drawings }\end{array}$ & $\begin{array}{l}\text { 1. Critical to quality } \\
\text { parameters are not } \\
\text { properly defined or even } \\
\text { missed. } \\
\text { 2. Tolerances for CTQ } \\
\text { parameters are too narrow } \\
\text { 3. Management of } \\
\text { changes is missing or not } \\
\text { followed }\end{array}$ & $\begin{array}{l}\text { 1.Dificult to manage } \\
\text { customer important } \\
\text { parameters } \\
\text { 2. Machinery is not able to } \\
\text { reach adequate } \mathrm{C}_{\mathrm{pk}} \text { level } \\
\text { 3. Own production uses } \\
\text { different drawing versions } \\
\text { than suppliers }\end{array}$ \\
\hline $\begin{array}{l}\text { 2. Product and } \\
\text { Process FMEA }\end{array}$ & $\begin{array}{l}\text { 1. Does not reflects } \\
\text { reality } \\
\text { 2. Out of date } \\
\text { 3.Insufficient quality }\end{array}$ & $\begin{array}{l}\text { 1. FMEA is elaborated for } \\
\text { an effect } \\
\text { 2. No feedback is realized } \\
\text { 3. Too shallow }\end{array}$ & $\begin{array}{l}1 \& 3 \text {. Unable to predict all } \\
\text { possible problems and } \\
\text { assure an adequate product } \\
\text { and process quality } \\
\text { 2. Does not reflect problems } \\
\text { \& events in connecting } \\
\text { processes }\end{array}$ \\
\hline 3. Control Plan & $\begin{array}{l}\text { 1. Insufficient quality } \\
\text { 3. Out of date }\end{array}$ & $\begin{array}{l}\text { 1. Some items \& means of } \\
\text { control improperly or not } \\
\text { defined } \\
\text { 2. No feedback realized }\end{array}$ & $\begin{array}{l}\text { 1. The plan does not fully } \\
\text { cover controlled area } \\
\text { 2. Disrespect of actions from } \\
\text { problem solving, claim, etc. }\end{array}$ \\
\hline $\begin{array}{l}\text { 4. Measurement } \\
\text { system analysis } \\
\text { (Gauge R\&R study) }\end{array}$ & $\begin{array}{l}\text { 1. Not available } \\
\text { 2. Non conform } \\
\text { results }\end{array}$ & $\begin{array}{c}\text { 1. Studies for certain } \\
\text { equipment are missing } \\
\text { 2. Some of the gauges are } \\
\text { not able to assure } R \& R \\
\text { level }\end{array}$ & $\begin{array}{l}\text { 1. \& 2. Not guaranteed level } \\
\text { of measurement quality and } \\
\text { results }\end{array}$ \\
\hline $\begin{array}{l}\text { 5. Results of part's } \\
\text { inspection }\end{array}$ & $\begin{array}{l}\text { 1.Incomplete } \\
\text { 2.Results out of } \\
\text { specifications }\end{array}$ & $\begin{array}{l}\text { 1. Some dimensions are } \\
\text { not measured at all } \\
\text { 2. Some dimensions are } \\
\text { out of tolerance }\end{array}$ & $\begin{array}{l}\text { 1. The insight to quality is } \\
\text { missing \& can bring } \\
\text { problems in serial } \\
\text { production }\end{array}$ \\
\hline
\end{tabular}




\begin{tabular}{|c|c|c|c|}
\hline & & & $\begin{array}{l}\text { 2. Impossibility to reach } \\
\text { expected quality level }\end{array}$ \\
\hline $\begin{array}{l}\text { 6. Results of material } \\
\text { tests }\end{array}$ & $\begin{array}{l}\text { 1. Not available } \\
\text { 2. Out of date }\end{array}$ & $\begin{array}{l}\text { 1. Supplier delay or } \\
\text { problem with quality } \\
\text { guarantee. } \\
\text { 2. Improper quality system }\end{array}$ & $\begin{array}{l}\text { 1.Mechanical , chemical \& } \\
\text { etc. characteristics are not } \\
\text { guaranteed } \\
\text { 2. Impossibility to guarantee } \\
\text { product quality }\end{array}$ \\
\hline $\begin{array}{l}\text { 7. Results of part's } \\
\text { functionality }\end{array}$ & $\begin{array}{l}\text { Does not meet } \\
\text { specifications }\end{array}$ & $\begin{array}{l}\text { Some parameters shows } \\
\text { discrepancy with different } \\
\text { impact }\end{array}$ & $\begin{array}{l}\text { Causing problems in serial } \\
\text { production and claims }\end{array}$ \\
\hline $\begin{array}{l}\text { 8.Initial process flow } \\
\text { study }\end{array}$ & $\begin{array}{l}\text { 1. Not available } \\
\text { 2. Results out of } \\
\text { specifications }\end{array}$ & $\begin{array}{l}\text { 1. The study has not been } \\
\text { carried out } \\
\text { 2. Some dimensions are } \\
\text { out of tolerance }\end{array}$ & $\begin{array}{l}\text { 1. Missing insight into the } \\
\text { manufacturing process. } \\
\text { 2. Impossibility to reach } \\
\text { expected quality level. } \\
\text { Unstable and unpredictable } \\
\text { manufacturing process. }\end{array}$ \\
\hline 9. Capability study & $\begin{array}{l}\text { 1.Some parameters } \\
\text { does not reach } \\
\text { required level } \\
\text { 2. Not available }\end{array}$ & $\begin{array}{l}\text { 1. Some parameters are } \\
\text { not able to be adjusted or } \\
\text { regulated due to } \\
\text { machinery set up or } \\
\text { conditions. Some } \\
\text { parameters are not } \\
\text { properly regulated. } \\
\text { 2. Not required by } \\
\text { customer }\end{array}$ & $\begin{array}{l}\text { 1\&2.Incapable products in } \\
\text { serial production, customer } \\
\text { jeopardy and cost of } \\
\text { corrective action and claims }\end{array}$ \\
\hline 10. Means of control & $\begin{array}{l}\text { 1. Not calibrated and } \\
\text { monitored } \\
\text { 2. Utilization of } \\
\text { different means and } \\
\text { methods of control }\end{array}$ & $\begin{array}{l}\text { 1. Not placed in MSA } \\
\text { system } \\
\text { 2. Supplier and customer } \\
\text { use different measurement } \\
\text { systems for particular } \\
\text { items }\end{array}$ & $\begin{array}{l}\text { 1. Does not guarantee } \\
\text { required measurement } \\
\text { quality and conformity with } \\
\text { etalon } \\
\text { 2. Different results and } \\
\text { disagreements on quality }\end{array}$ \\
\hline $\begin{array}{l}\text { 11. Initial samples } \\
\text { (production parts) }\end{array}$ & $\begin{array}{l}\text { 1. Dimensions out of } \\
\text { tolerance } \\
\text { 2. Parts incapable }\end{array}$ & $\begin{array}{l}\text { 1. Some dimensions are } \\
\text { out of tolerance } \\
\text { 2. Required quality } \\
\text { guarantee is not } \\
\text { accomplished }\end{array}$ & $\begin{array}{c}\text { 1\&2. Quality problems at } \\
\text { own assembly process and } \\
\text { customer }\end{array}$ \\
\hline $\begin{array}{l}\text { 12. Quality } \\
\text { engagements \& plan } \\
\text { of reaction }\end{array}$ & $\begin{array}{l}\text { 1. Not available } \\
2 \text { Too strict }\end{array}$ & $\begin{array}{c}\text { 1.No mutual agreement } \\
\text { between organizations is } \\
\text { established } \\
\text { 2. The quality engagement } \\
\text { are unreachable }\end{array}$ & $\begin{array}{l}\text { 1.Leads to non-conform } \\
\text { deliveries and enforces } \\
\text { claims } \\
\text { 2. Laxity from supplier side } \\
\text { and ignored a priori }\end{array}$ \\
\hline $\begin{array}{l}\text { 13. Qualified } \\
\text { laboratory } \\
\text { documentation }\end{array}$ & Not available & $\begin{array}{l}\text { Calibration records for } \\
\text { gauges, equipment, } \\
\text { sensors etc. are missing }\end{array}$ & $\begin{array}{l}\text { Enable to assure quality of } \\
\text { product and process }\end{array}$ \\
\hline $\begin{array}{l}\text { 14. Mutually beneficial } \\
\text { contract between } \\
\text { supplier \& customer }\end{array}$ & $\begin{array}{l}\text { Improper or } \\
\text { imperfect }\end{array}$ & $\begin{array}{l}\text { Missing some items or } \\
\text { poorly defined }\end{array}$ & $\begin{array}{l}\text { Problems with quality, } \\
\text { communication, problem } \\
\text { solving, claim management, } \\
\text { and cooperation }\end{array}$ \\
\hline
\end{tabular}

Source: (Own study)

Common factors of above described non-compliances and their consequences might be summarized into following areas: 
Table 3

Common factors of non-compliances stemming from ISO/TS 16949:2009 requirements

\begin{tabular}{|l|}
\hline 1. A breach of prescribed procedures \\
\hline $\begin{array}{l}\text { 2. Activity (process, item etc.) has not been performed in terms of satisfactory competence, } \\
\text { discipline and willingness, or knowledge }\end{array}$ \\
\hline 3. Insufficient monitoring of process realization and fulfillment \\
\hline 4. Missing control mechanisms, activities, and verifications \\
\hline 5. Missing personal responsibility, reliability, vigor, and accuracy \\
\hline
\end{tabular}

Source: (Own study)

\section{DISCUSSION}

Based on the results obtained as systemic approach is an introduction and deployment of fundamental quality tools. The system activities for supplier's parts quality assurance can be visualized in a form of pyramid surrounded by walls. The first quality wall represents a fundamental protection system of customer production line in order to prevent it from intruding of defective parts. It is generally organized in a form of incoming inspection and realized as sampling. The pyramid foundation stone forms a set of corrective actions when non-compliant part occurs, including $100 \%$ control when an established team with cooperation of supplier sorts potential defective parts.

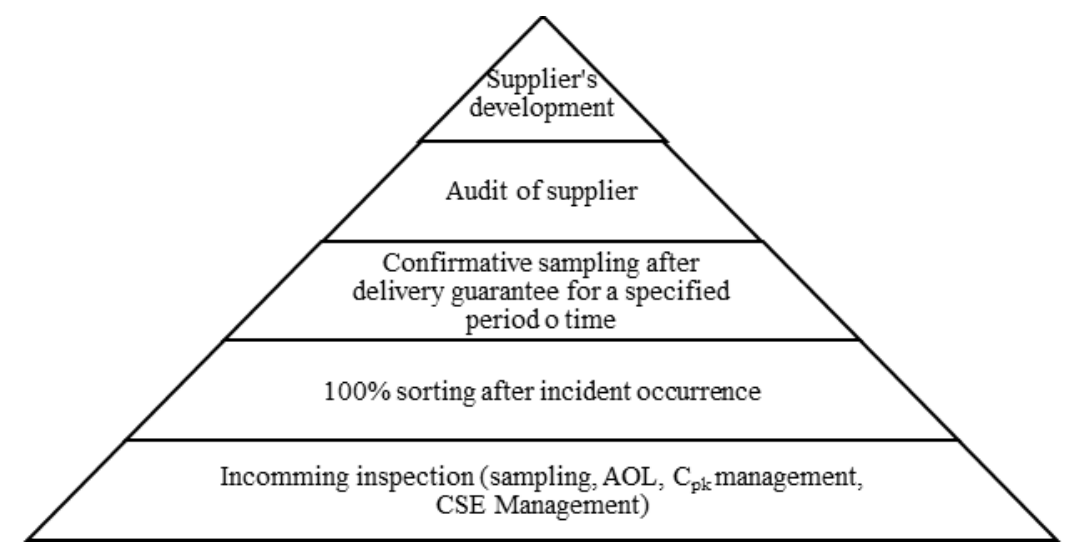

Fig. 2. An organization of protection against non-compliant supplier parts

Following stone presents a sample control for assurance of deliveries after a quality incident for a specified period of time. The additional stones serve as activities focused on supplier's development (quality audits, training, supervision, monitoring, and evaluation). The second quality wall (fire wall) represents a system of final customer protection. The further countermeasures and remedy associated with the supplier quality management and performance are depicted in table 4. 
Table 4

Countermeasures and remedy associated with the supplier quality management and performance

1. Create and develop a simple, reasonable, and understandable procedures and tools as well as mechanisms for their successful control.

2. Repeatedly educate and motivate employees in branch of quality in order to know, understand, and properly use quality tools and create the quality awareness as priority.

3. Establish an advanced control and monitoring system based on SPC, AOL, and capability indices philosophy with inherent PDCA cycle and transfer it to suppliers.

4. Based on thorough full process analysis define weak areas and develop mechanisms and tools for control, examination, and verification.

5. Develop a recruitment system and policy that prefers and supports the focus on important employee's characteristics particularly the reliability, responsibility, loyalty, precision, activity, accuracy, and vigor.

Source: (Own study)

\section{CONCLUSION}

Considering above mentioned non-compliances and their consequences the presented list neither does nor represents all possible eventualities. All described items and experiences were gathered during internal and external audits in automotive industry across the Europe. The recommended conclusions and corrective actions were implemented and their efficiency verified bringing positive changes in terms of quality, costs, and delivery goals. Summarizing described observations it is crucial for the company in terms of elimination the quality problems with suppliers and own processes to define actual or potential risks in processes and their interfaces. Based on table 3 the common non-compliances factors are: breaching or circumvention of procedures, incompetence, ignorance, unwillingness and problems with discipline. Furthermore, it is also insufficient monitoring and PDCA ignorance or strict implementation, missing control mechanisms, verification, and finally weak personal characteristics or policy within the organization. There have been determined five areas for an improvement in the previous paragraph as well. These particular areas are linked to creation of robust procedures and control mechanisms, personnel repeated education and training on quality principles, tools, and awareness. Moreover, the remedy covers the establishment of statistical based tools and monitoring system including capability point of view within own factory with additional transfer to suppliers. Eventually, to define and develop mechanisms and tools for control, examination, verification, and to create rules and policy focused on selection and support of employees with necessary characteristics. The non-compliances determination, description, and elimination can definitely bring a prerequisite of smooth flawless manufacturing process reaching customer expectations and quality goals. 


\section{REFERENCE}

Bergman, B., Klefsjö, B., 2010. Quality from Customer Needs to Customer Satisfaction. Elanders Hungary, ISBN 978-91-44-05942-6.

CSJ, 2009. ISO/TS 16949:2009. Praha, ISBN 978-80-02-02176-6.

CSJ, 2006. Proces schvalovani dilu do seriove vyroby (PPAP). Praha, ISBN 8001833-8.

CSJ, 2008. Moderni planovani kvality vyrobku (APQP). Praha, ISBN 978-80-0202142-1.

Dian, M., 2012. Contemporary Problems with Manufactured Product and Tools for Problem Solving. Monograph Toyotarity. Materials and Special Purpose Products Quality. University of Maribor, pp 100-114. ISBN 978-961-6562-61-4.

Dian, M., 2010. Internal unpublished audits conclusions from PSA, Renault, Toyota, Nissan.

Dian, M., 2014. The G8D Tool for Risk Elimination, Factor of Problem Prevention and Reccurence in Manufacturing Processes. In: Rizika podnikovych procesu. JEP University in Usti nad Labem. ISBN 978-80-7414-766-1.

FAU-C-SP-4030/EN, 2002. Quality Supplier`s Guide.

Horvath, G., 2012. Vychodiska pro rozbor a hodnocení rizik podnikovych procesu vyroby soucasti a montaze. In: Rizika vybranych podnikových procesů. JEP University in Usti nad Labem. ISBN 978-80-7414-522-3.

Kano, N., 2019. A-TQM and Kano Model Focused on Customer Delight Beyond Customer Satisfaction. Ljublana, Slovenia, Bureau Veritas.

Kocour, P., 2012. Rizika procesu nakupu a zasobovani vyroby materialem. In: Rizika vybranych podnikovych procesu. JEP University in Usti nad Labem, ISBN 978-807414-522-3.

PSA, 2006. Supplier Quality Management Principles. 